DOI: $10.17816 /$ ecogen16355-61

\title{
EVALUATION OF MUTAGENIC AND ANTIMUTAGENIC POTENTIAL OF STEM BARK AQUEOUS EXTRACTS OF EIGHT TREES BY THE BACTERIAL REVERSE MUTATION ASSAY
}

\author{
(c) E.Y. Abdul-Hafeez ${ }^{1}$, N.S. Karamova ${ }^{2}$, O.N. Ilinskaya ${ }^{2}$
}

\author{
${ }^{1}$ Assiut University, Assiut, Egypt; \\ ${ }^{2}$ Kazan (Volga region) Federal University, Kazan, Russia
}

For citation: Abdul-Hafeez EY, Karamova NS, Ilinskaya ON. Evaluation of mutagenic and antimutagenic potential of stem bark aqueous extracts of eight trees by the bacterial reverse mutation assay. Ecological genetics. 2018;16(3):55-61. doi: 10.17816/ecogen16355-61.

Stem bark aqueous extracts of eight woody plants Brachychiton populneus, Ceiba pentandra, Bombax malabaricum, Chorisia speciosa, Albizia lebbeck, Bauhinia variegata, Kigelia africana and Pinus halepensis were tested for their mutagenic and antimutagenic potential in the Ames test with Salmonella typhimurium strains TA98 and TA100. The aqueous extracts were neither toxic nor mutagenic in S. typhimurium tester strains. All of the tested extracts showed detectable antimutagenic effect towards the direct acting mutagens 2-nitrofluorene (2-NF) in TA98 as well as sodium azide in TA100. The extract from Kigelia africana was the most effective in reducing the mutagenicity caused by the direct mutagen $2-\mathrm{NF}$ in the TA98 with $85.42 \%$ inhibition rate. A. lebbeck stem bark extract demonstrated the highest antimutagenic activity reducing the base substitution mutations rate for strain TA100 by $94.66 \%$ in pre-incubation assay. The results obtained showed that the stem bark aqueous extracts tested can protect cells against induced gene mutations.

Keywords: Mutagenicity; antimutagenicity; medicinal plants; Ames test; Salmonella typhimurium strains; stem bark extracts.

\section{INTRODUCTION}

In the last 20 years, the interest in medicinal plants has increased together with the number of investigations into their biological effects on human beings. Today plant-derived systems play an essential role in healthcare [1,2,3]. Investigation into traditionally used medicinal plants is valuable for the screening and development of potential chemotherapeutic drugs and for establishing the safety of their continuous use. Thus, studies for their cytotoxic, mutagenic as well as antimutagenic potential are necessary to support the safe use of medicinal plants.

It has been postulated that mutations play a key role in carcinogenesis process and can also contribute to the pathogenesis of other chronic diseases, such as atherosclerosis, neurodegenerative diseases, degenerative hearth diseases, glaucoma etc. [4]. Thereby, the research work related to the discovery, characterisation and use of antimutagens is very important. Plants are the promising source of antimutagens which occur in them as secondary metabolites. Several plant extracts or their constituents have proved to contain a variety of antimutagenic and antigenotoxic compounds [5, 6, $7,8,9]$. These antimutagens may help in strengthening cellular defences against environmental mutagens/ stress and thus preventing the development of several mutation-related diseases.

In this work we assessed the mutagenic and antimutagenic potential of certain stem bark aqueous extracts from eight woody plants by using bacterial reverse mutation assay.

\section{MATERIALS AND METHODS}

\subsection{Plant materials}

Stem bark of eight trees: Brachychiton populneus Schott \& Endl., Ceiba pentandra L., Bombax malabaricum DC, Chorisia speciosa A.St.-Hil., Albizia lebbeck (L.) Benth., Bauhinia variegata L., Kigelia africana (Lam.) Benth. and Pinus halepensis Miller were collected from the botanical gardens of Faculty of Agriculture, Assiut University, Assiut, Egypt. Botanical identification was carried out by the Botanists, Faculty of Science, Assiut University. The stem bark samples of plants were cleaned, shade dried, powdered and stored in the dark under refrigerated conditions.

\subsection{Preparation of plant extracts}

The plant material powder $(1 \mathrm{~g})$ was macerated in distilled water $(10 \mathrm{ml})$ during $48 \mathrm{~h}$ with continuous stirring at room temperature. Afterwards, the extracts were filtered with a Whatman No. 1 filter paper and sterilized using $0.22 \mu \mathrm{m}$ Millipore membrane filters. The experiments were performed at concentration of $100 \mu \mathrm{l} /$ plate, corresponding to $10 \mathrm{mg} /$ plate dry plant matter, respectively.

\subsection{Bacterial strains}

Histidine auxotrophic strains of Salmonella typhimurium TA98 (hisD3052 rfa $\triangle u v r B$ bio- ${ }^{-}$KM101) and TA100 (his G46 rfa $\Delta u v r \mathrm{~B}$ bio $\mathrm{pKM101}$ ) were obtained from the Department of Genetics of Lomonosov Moscow State University (Moscow, Russia). Strain TA98 was used for determining the frameshift and TA100 was used to determine the base pair exchange mutations. The genetic characteristics of each strain were tested as recommended [10]. 


\subsection{Chemicals}

2-Nitrofluorene (2-NF) and sodium azide $\left(\mathrm{NaN}_{3}\right)$ were purchased from Sigma Chemical Co., St. Louis. Ampicillin and dimethyl sulfoxide (DMSO) from Merck (Germany) were also used.

\subsection{Mutagenicity assay}

In preliminary study all the extracts were tested for toxicity with the Salmonella typhimurium strain TA98. In the cytotoxicity assay, $S$. typhimurium cells mixed with $100 \mu \mathrm{l}$ of plant extract were plated and grown on nutrient agar plates, as reported previously [10]. The extract samples with $>50 \%$ viable cells were considered non-toxic compared with the viability of the negative (solvent) control.

The Ames assay was performed as earlier [10, 11] using the plate incorporation method. The test strains were grown in nutrient broth supplemented with $25 \mu \mathrm{g} / \mathrm{ml}$ ampicillin to a density of $1-2 \times 10^{9}$ cells $/ \mathrm{ml}$. $100 \mu$ of each plant extract were added to $2 \mathrm{ml}$ of $45^{\circ} \mathrm{C}$ molten top agar, supplemented with $0.5 \mathrm{mM}$ L-histidine and $0.5 \mathrm{mM}$ D-biotine, mixed with $100 \mu$ of bacterial culture and then poured on to a plate containing minimal glucose agar medium. Then the plates were incubated at $37^{\circ} \mathrm{C}$ for $48-72 \mathrm{~h}$. The numbers $\mathrm{His}^{+}$revertant colonies per plate were counted. All samples were tested in three independent experiments with triplicate plates. Negative (solvent) and positive controls were included in each experiment. 2 - NF dissolved in DMSO ( $2 \mu \mathrm{g} /$ plate) for strain TA98 and $\mathrm{NaN}_{3}$ dissolved in distilled water ( $4 \mu \mathrm{g} /$ plate $)$ for strain TA100 were used as a positive control to ensure that the assay was working efficiently.

\subsection{Antimutagenicity assay}

Co-incubation of plant extracts with mutagens and Salmonella typhimurium strains

Antimutagenic potential of aqueous extracts was determined with the $S$. typhimurium strains TA98 and TA100 in the basis of described Ames test [10, 11]. In the antimutagenicity assay, the samples of extracts that had neither toxic nor mutagenic effects on the $S$. typhimurium cells were used.

Here, $100 \mu \mathrm{l}$ of tester strain culture with a density of $1-2 \cdot 10^{9}$ cells $/ \mathrm{ml}, 100 \mu \mathrm{l}$ of the aqueous stem bark extract to be tested mixed with $100 \mu \mathrm{l}$ of mutagen solution, and $2 \mathrm{ml}$ of molten top agar supplemented with $0.5 \mathrm{mM}$ L-histidine and $0.5 \mathrm{mM} \mathrm{D}$-biotin were added to each tube. The mixture was poured onto minimal glucose agar plates. The plates were incubated for $48-72 \mathrm{~h}$ at $37{ }^{\circ} \mathrm{C}$ and then the $\mathrm{His}^{+}$revertants colonies were scored. The antimutagenicity was expressed as percentage of inhibition calculated by the following equation $[12,13]$ :

Inhibition $(\%)=[1-\mathrm{T} / \mathrm{M}] \times 100 \%$

where $\mathrm{T}$ is the number of revertants per plate in the presence of mutagen and plant extract and $M$ is the number of revertants per plate in the positive control. The number of spontaneous revertants was subtracted from the numerator and denominator.
The antimutagenic effect was considered strong and moderate when the inhibition effect was higher than $40 \%$ or between $25 \%$ and $40 \%$, respectively. An inhibition effect less than $25 \%$ was not considered a positive result $[13,14]$.

1.7. Pre-incubation of plant extracts with $S$. typhimurium strains

To determine the effect of pre-incubation of plant extracts with $S$. typhimurium strains, a mixture consisting of $100 \mu \mathrm{l}$ of extract to be tested and $100 \mu \mathrm{l}$ of $S$. typhimurium strain TA98 or TA100 culture was incubated at $37^{\circ} \mathrm{C}$ for $30 \mathrm{~min}$ with gentle shaking. Then, $100 \mu \mathrm{l}$ of $20 \mu \mathrm{g} / \mathrm{ml}$ of 2 -NF for strain TA98 or $40 \mu \mathrm{g} / \mathrm{ml}$ of $\mathrm{NaN}_{3}$ for strain TA100 were added to the mixture. The antimutagenicity assay was performed as mentioned above.

\subsection{Statistical analysis}

The results were expressed as mean \pm SD of of three independent experiments (three replications per sample in each experiment). The one-way ANOVA test was used to analyse the result and $P<0.05$ was considered significant.

\section{RESULTS}

\subsection{Mutagenicity testing}

To examine the effect of plant extracts on viability of S. typhimurium tester strains used in mutagenicity and antimutagenicity tests, we conducted the preliminary cytotoxicity assay with $S$. typhimurium strain TA98. Our data (Table 1) show that no toxic effect was observed for any extracts using $S$. typhimurium strain TA98. A good survival degree of the $S$. typhimurium cells (>50\%) was found after all the extracts samples exposure. Thus, all

Table 1

Salmonella typhimurium TA98 cell viability after exposure to tree stem bark aqueous extracts

\begin{tabular}{|l|c|c|}
\hline \multicolumn{1}{|c|}{ Samples } & $\begin{array}{c}\text { Number of CFU/ } \\
\text { plate* }\end{array}$ & Viability, \% \\
\hline Control & $34.0 \pm 2.10$ & - \\
\hline $\begin{array}{l}\text { Brachychiton } \\
\text { populneus }\end{array}$ & $22.11 \pm 1.53$ & 65.03 \\
\hline Ceiba pentandra & $30.23 \pm 4.16$ & 88.91 \\
\hline $\begin{array}{l}\text { Bombax } \\
\text { malabaricum }\end{array}$ & $31.16 \pm 1.52$ & 91.64 \\
\hline Chorisia speciose & $29.23 \pm 2.08$ & 85.97 \\
\hline Albizia lebbeck & $24.97 \pm 2.36$ & 73.44 \\
\hline Bauhinia variegata & $27.02 \pm 3.05$ & 79.47 \\
\hline Kigelia africana & $22.87 \pm 2.51$ & 67.26 \\
\hline Pinus halepensis & $24.68 \pm 2.08$ & 72.59 \\
\hline $\begin{array}{l}\text { Note: } * \text { Number of colony-forming units per plate (mean va- } \\
\text { lue } \pm \text { SD). Viability percentages are given taking the count } \\
\text { (CFU/plate) of control (S. typhimurium TA98 cells without ex- } \\
\text { tracts samples) as } 100 \%\end{array}$ \\
\hline
\end{tabular}


Mutagenic potential of tree stem bark aqueous extracts in Salmonella typhimurium strains TA100 and TA98

\begin{tabular}{|c|c|c|}
\hline \multirow{2}{*}{ Samples } & \multicolumn{2}{|c|}{ Number of $\mathrm{His}^{+}$revertants/plate } \\
\hline & TA98 & TA100 \\
\hline Negative control & $22.00 \pm 6.00$ & $135.75 \pm 27.25$ \\
\hline Positive control & $696.00 \pm 36.00^{*}$ & $1248.90 \pm 137.00^{*}$ \\
\hline Brachychiton populneus & $25.00 \pm 5.00$ & $148.00 \pm 22.00$ \\
\hline Ceiba pentandra & $25.33 \pm 5.51$ & $145.00 \pm 24.00$ \\
\hline Bombax malabaricum & $16.00 \pm 1.00$ & $130.00 \pm 11.00$ \\
\hline Chorisia speciose & $27.33 \pm 0.58$ & $162.00 \pm 9.10$ \\
\hline Albizia lebbeck & $13.00 \pm 1.00$ & $121.00 \pm 6.00$ \\
\hline Bauhinia variegata & $32.33 \pm 4.51$ & $106.00 \pm 7.00$ \\
\hline Kigelia africana & $22.33 \pm 0.58$ & $144.70 \pm 12.51$ \\
\hline Pinus halepensis & $29.33 \pm 6.51$ & $148.50 \pm 10.50$ \\
\hline
\end{tabular}

Table 3

Antimutagenic effect of tree stem bark aqueous extracts in Salmonella typhimurium tester strains TA98 and TA100

\begin{tabular}{|c|c|c|c|c|}
\hline \multirow[b]{2}{*}{ Samples } & \multicolumn{2}{|c|}{ TA98 } & \multicolumn{2}{|c|}{ TA100 } \\
\hline & $\begin{array}{l}\text { Number of } \mathrm{His}^{+} \\
\text {revertants/plate }\end{array}$ & Inhibition rate (\%) & $\begin{array}{l}\text { Number of } \text { His }^{+} \\
\text {revertants/plate }\end{array}$ & Inhibition rate $(\%)$ \\
\hline Negative control & $22.00 \pm 6.00$ & - & $135.75 \pm 27.25$ & - \\
\hline Positive control & $696.00 \pm 36.00$ & - & $1248.90 \pm 137.00$ & - \\
\hline Brachychiton populneus & $186.33 \pm 45.50^{*}$ & 75.62 & $677.00 \pm 31.00^{*}$ & 51.38 \\
\hline Ceiba pentandra & $190.33 \pm 53.50^{*}$ & 75.03 & $403.00 \pm 72.00^{*}$ & 75.99 \\
\hline Bombax malabaricum & $225.33 \pm 81.50^{*}$ & 69.83 & $458.00 \pm 12.00^{*}$ & 71.05 \\
\hline Chorisia speciosa & $216.33 \pm 2.52^{*}$ & 71.17 & $794.00 \pm 23.00^{*}$ & 40.87 \\
\hline Albizia lebbeck & $156.00 \pm 49.00^{*}$ & 80.12 & $589.00 \pm 74.00^{*}$ & 59.28 \\
\hline Bauhinia variegata & $164.00 \pm 11.00^{*}$ & 78.93 & $580.00 \pm 17.00^{*}$ & 60.11 \\
\hline Kigelia africana & $120.33 \pm 15.50^{*}$ & 85.42 & $897.00 \pm 92.00$ & 31.61 \\
\hline Pinus halepensis & $217.33 \pm 3.51^{*}$ & 71.02 & $553.00 \pm 17.00^{*}$ & 62.52 \\
\hline
\end{tabular}

eight stem bark aqueous extracts can be investigated for their mutagenic and antimutagenic potential in $S$. typhimurium strains TA98 and TA100 without the risk of obtaining false-negative results.

Results of the mutagenicity assay of plant extracts are presented in Table 2. Colony counting in the Ames test showed that there was no essential difference in the numbers of $\mathrm{His}^{+}$revertant colonies induced by stem bark aqueous extracts and spontaneous background for $S$. typhimurium strain TA98 as well as for strain TA100. These results suggest that all tested aqueous extracts do not possess mutagenicity in $S$. typhimurium strains TA98 and TA100. On the other hand, the numbers of $\mathrm{His}^{+}$revertants induced by positive control mutagens (2-NF and $\mathrm{NaN}_{3}$ ) significantly increased the spontaneous mutation rate in the both $S$. typhimurium tester strains.

2.2. Antimutagenic effects of tree stem bark aqueous extracts

Table 3 shows the data obtained in antimutagenicity assessment of the extracts in relation to $2-\mathrm{NF}$ and $\mathrm{NaN}_{3}$ using co-incubation protocol. Antimutagenic effect against sodium azide was more pronounced than 2-NF. The Kigelia africana aqueous extract was the most effective in reducing the mutagenicity caused by the direct mutagen $2-\mathrm{NF}$ in the TA98 with $85.4 \%$ inhibition. The inhibitory effect exerted by the extracts for base pair sutstituation mutaions induced by $\mathrm{NaN}_{3}$ in the TA100 ranged from $31.6 \%$ to $75.9 \%$. 
Table 4

Antimutagenic effect of tree stem bark aqueous extracts in the pre-incubation assay with Salmonella typhimurium tester strains TA98 and TA100

\begin{tabular}{|c|c|c|c|c|}
\hline \multirow[b]{2}{*}{ Samples } & \multicolumn{2}{|c|}{ TA98 } & \multicolumn{2}{|c|}{ TA100 } \\
\hline & $\begin{array}{l}\text { Number of } \mathrm{His}^{+} \\
\text {revertants/plate }\end{array}$ & Inhibition rate (\%) & $\begin{array}{l}\text { Number of } \mathrm{His}^{+} \\
\text {revertants/plate }\end{array}$ & Inhibition rate ( $\%)$ \\
\hline Negative control & $14.330 \pm 3.51$ & - & $123.33 \pm 21.00$ & - \\
\hline Positive control & $680.00 \pm 16.00$ & - & $1134.70 \pm 231.00$ & - \\
\hline Brachychiton populneus & $536.00 \pm 52.00$ & 21.63 & $235.00 \pm 17.00^{*}$ & 88.96 \\
\hline Ceiba pentandra & $470.00 \pm 22.00$ & 31.55 & $217.00 \pm 19.00^{*}$ & 90.74 \\
\hline Bombax malabaricum & $430.00 \pm 6.00$ & 37.56 & $230.33 \pm 21.16^{*}$ & 89.22 \\
\hline Chorisia speciosa & $426.00 \pm 12.00^{*}$ & 38.16 & $220.00 \pm 36.00^{*}$ & 90.44 \\
\hline Albizia lebbeck & $245.00 \pm 93.00^{*}$ & 65.35 & $177.33 \pm 43.00^{*}$ & 94.66 \\
\hline Bauhinia variegata & $150.00 \pm 38.00^{*}$ & 79.62 & $247.33 \pm 27.12^{*}$ & 87.73 \\
\hline Kigelia africana & $131.00 \pm 29.00^{*}$ & 82.47 & $232.33 \pm 8.72^{*}$ & 89.22 \\
\hline Pinus halepensis & $524.00 \pm 98.00$ & 23.44 & $254.00 \pm 5.70^{*}$ & 88.07 \\
\hline
\end{tabular}

Table 4 illustrates the antimutagenic potential of eight tree stem bark aqueous extracts when tested using the pre-incubation protocol. Varying effects of plant extracts on direct-acting mutagens $2-\mathrm{NF}$ and $\mathrm{NaN}_{3}$ were obtained. It should be emphasised that, in general, the inhibitory effect of stem bark extracts against $\mathrm{NaN}_{3}$ in the strain TA100 (87.7-94.7\%) was higher than against $2-\mathrm{NF}$ in TA98 (21.6-82.5\%). At the same time, Kigelia africana extract significantly decreased the number of induced $\mathrm{His}^{+}$ revertant colonies in both tester strains. Inhibition percentages were $81.2 \%$ and $89.2 \%$ for $2-\mathrm{NF}$ and $\mathrm{NaN}_{3}$, respectively. Albizia lebbeck demonstrated the highest antimutagenic activity $(94.7 \%)$ in the TA100 strain in pre-incubation assay.

\section{DISCUSSION}

The results obtained from this study showed that all aqueous extracts of the stem bark of eight trees are not mutagenic in bacterial reverse mutation assay. The number of revertants caused by the extracts tested was not two-fold higher than that obtained with negative control [11]. Thus, any of these extracts did not induce base pair substitution as well as frameshift gene mutations in bacterial cells (S. typhimurium strains TA98 and TA100). There are limited data on the genotoxic properties of extracts prepared from plant species used in the present work. Nevertheless, the results of our investigation are similar to the other published data. According to data obtained by Eldeen et al. [15], bark and root extracts of Kigelia africana were not mutagenic in the Ames assay. Pandey and Agrawal [16] reported that Bauhinia variegata bark extract did not demonstrate significant genetic toxicity in mouse bone marrow cells. Yim et al. [17] performed in silico screening of 9 compounds found in the bark of Albizia lebbeck for their potential side effects like tumorigenicity, mutagenicity etc. According to their data, D-catachin, melacidin, lebbecacidin, leucocynadin, the most important components of Albizia lebbeck bark, do not possess mutagenic and tumorigenic potential.

All of the tested extracts showed detectable antimutagenic effect towards the direct-acting mutagens $2-\mathrm{NF}$ as well as $\mathrm{NaN}_{3}$ after the simultaneous treatment of tester strains cells with mutagens and extracts. Significant survival results for $S$. typhimurium tester strain TA98 exposed to all eight aqueous extracts alone in a toxicity assay verify that the decrease in the number of $2-\mathrm{NF}$ and $\mathrm{NaN}_{3}$-induced His ${ }^{+}$revertants in the presence of aqueous extracts in the Ames assay is due to their antimutagenic effects. The extracts were somewhat more active in inhibiting frameshift mutations in TA98 than in TA100, with base pair substitution mutations. We observed strong antimutagenic activity of all aqueous extracts against $2-\mathrm{NF}$ while inhibition rate of $\mathrm{NaN}_{3}$ mutagenicity was lower, especially for extracts of Kigelia africana, Chorisia speciosa and Brachychiton populneus. At the same time, preliminary incubation of tester strains with stem bark aqueous extracts results in an increase of the antimutagenic effect of extracts towards $\mathrm{NaN}_{3}$ in strain TA100 (87.73-94.66\%). However, we observed a lower inhibitory effect against 2 -NF under these conditions.

The application of protocols of co-incubation, pre-incubation with plant extracts and the known mutagens allows us to suggest the mechanisms of the antimutagenic effect of plant extracts tested. It is known that antimutagens are classified into two groups: desmutagens and bioantimuta- 
gens [18]. Desmutagens inactivate mutagens by bounding or chemical modification of its molecule directly. Bioantimutagens block the mutagenic process by modification of the transmembrane transport of mutagens, activating the error-free DNA repair system, and increasing the fidelity of DNA replication or modulation of chemical compound biotransformation and etc. [4, 5, 19].

$2-\mathrm{NF}$ is a direct acting mutagen and carcinogen; its mutagenicity has been determined in microbial test-systems and proved on experimental animals. In the Ames assay, 2-NF nitroreduction followed by $\mathrm{O}$-acetylation is a critical pathway that leads to mutagenesis [20, 21]. Paul et al. [22] showed the possibility of 2-NF nitroreduction by human microflora in female Wistar rats. It has also been proposed that the mutagenicity of 2 -NF in bacterial cells may be partly connected to oxidative stress. Salmonella tester strains that are deficient in 8-oxo-guanine DNA glycosylase demonstrated increased mutagenic activity after incubation with 2 -NF. It suggests that the reduction of 2 -NF nitro groups results in the formation of reactive oxygen species (ROS) which cause DNA lesions such as 8-hydroxydeoxyguanosine [23, 24].

High inhibition of the 2-NF mutagenicity after co-incubation with all tested plant extracts suggests that their activity could be essentially assigned to desmutagenic effects. Inactivation of the compound before its biotransformation by bacterial enzymes seems to be the dominant antimutagenic mechanism of the extracts against the effect of 2 -NF. On the other hand, we observed strong antimutagenic activity of aqueous extracts of three plants Kigelia africana, Bauhinia variegata, Albizia lebbeck towards $2-\mathrm{NF}$ in a pre-incubation assay. Based on our results, we can propose that these extracts decrease the mutagenicity of 2 -NF by combining desmutagenic and bioantimutagenic effects.

Sodium azide, another mutagen used in this work is known to be highly mutagenic in many bacterial and plant species [25-28]. The mutagenicity of $\mathrm{NaN}_{3}$ is mediated through the production of L-azidoalanine catalysed by the enzyme $\mathrm{O}$-acetylserine sulphydrylase. This metabolite interacts with DNA and induces gene mutations [27, 29].

The results obtained in this study indicate that the pre-treatment of bacterial cells with stem bark aqueous extracts led to a decrease of $\mathrm{NaN}_{3}$ mutagenicity. This could be explained by the fact that tested extracts induce changes in membrane permeability and protect cells against $\mathrm{NaN}_{3}$ mutagenicity as a consequence. We cannot, however, exclude that a remarkable decrease of $\mathrm{NaN}_{3}$ mutagenicity in the pre-incubation assay could be associated with suppressing the metabolic activation of the mutagen, particularly blocking of the enzyme $\mathrm{O}$-acetylserine sulphydrylase activity or activating DNA repair enzymes as well.

The protective effect of aqueous extracts observed in the present study may correspond to several compounds of plants and their synergic participation. Polyphenols con- stitute one of the most important groups among a various number of secondary metabolites produced by plants. Many plant polyphenols, such as ellagic, caffeic and ferulic acids, catechins have been shown to possess antimutagenic and anticarcinogenic activity $[30,31,32]$. It has been suggested that such activity is attributed to their antioxidant effects. Thus, good correlation between the in vitro antioxidant activity of certain natural compounds such as green tea catechins, sesamol etc. and their antimutagenic activity have been reported $[33,34,35]$. The antioxidant activity of phenolic compounds has mainly been associated with their redox properties, hydrogen donors and singlet oxygen quenchers.

Results of the presented work supported the previously reported antimutagenic activity of Kigelia africana leaves flavonoids assessed using cyclophosphamide induced micronuclei formation and chromosomal aberrations in mouse bone marrow [36]. It has previously been demonstrated that methanol extracts of Bauhinia variegata bark shows protective effect against $\mathrm{H}_{2} \mathrm{O}_{2}$ induced pBR322 DNA damages [37] and cyclophosphamide induced micronuclei formation in Swiss bone marrow cells [16].

The data of the present study allow us to consider the extracts tested as a promising source of components with antimutagenic and potential chemopreventive activity as a result. The further identification and characterisation of the compounds present in the stem bark extracts tested to determine their role in antimutagenicity will provide important data to create new effective chemoprophylactic agents and reduce the risk of cancer.

\section{CONCLUSIONS}

The results of this study indicate that the Kigelia africana aqueous extract is very effective in reducing the mutagenicity caused by the direct mutagen 2 -NF in the TA98 with $85.42 \%$ inhibition rate. The extract obtained from Albizia lebbeck demonstrated the highest antimutagenic activity decreasing the base substitution mutations rate by $94.66 \%$ in pre-incubation assay. Thus, the stem bark aqueous extracts tested can protect cells against induced gene mutations and could be used for development of functional food and new chemopreventive agents.

\section{ACKNOWLEDGMENTS}

This work was supported by the subsidy of the Russian Government to support the Program of Competitive Growth of Kazan Federal University among World's Leading Academic Centers and the Russian Foundation for Basic Research (RFBR grant number 15-54-61024).

\section{REFERENCES}

1. Craig WJ. Health-promoting properties of common herbs. Am J Clin Nutr. 1999;70(3):491S-499S. doi: 10.1093/ajen/70.3.491s. 
2. Junior VF, Pinto AC, Maciel MA. Plantas medicinais: cura segura? Quim Nova. 2005;28(3):519-528. doi: 10.1590/S0100-40422005000300026.

3. Farnsworth NR, Akerele O, Bingel AS, et al. Medicinal plants in therapy. Bull World Health Organ. 1985;63(6):965-981.

4. De Flora S, Ferguson LR. Overview of mechanisms of cancer chemopreventive agents. Mutat Res. 2005;591(1-2): 8-15. doi: 10.1016/j.mrfmmm.2005.02.029.

5. Bhattacharya S. Natural antimutagens: A Review. Res J Med Plant. 2011;5(2):116-126. doi: 10.3923/ rjmp.2011.116.126.

6. Sangwan S, Shanker S, Sangwan RS, Kumar S. Plant-derived products as antimutagens. Phytother Res. 1998;12(6):389-399. doi: 10.1002/(SICI)10991573(199809)12:6<389:: AID-PTR327>3.0.CO;2-S.

7. Karamova NS, Fatykhova DG, Abdrakhimova JR, Ilinskaya ON. An investigation of antigenotoxic properties of plant extracts of Chelidonium majus L., Plantago major L. and Tussilago farfara L. Russian Journal of Genetics: Applied Research. 2011;1(5):371-378. doi: 10.17816/ecogen8256-65.

8. Karamova N, Gumerova S, Hassan OG, et al. Antioxidant and antimutagenic potential of extracts of some Agavaceae family plants. BioNanoScience. 2016;6(4):591 -593. doi: 10.1007/s 12668-016-0286-x.

9. Srividya AR, Dhanabal SP, Vishnuvarthan VJ. Mutagenicity/Antimutagenicity of plant extracts used in traditional medicine: a review. World J Pharm Res. 2012;2( 1$): 236-259$.

10. Maron DH, Ames BN. Revised methods for the Salmonella typhimurium mutagenicity test. Mutat Res. 1983;113(3-4):73-215. doi: 10.1016/b978-0-44480519-5.50011-0.

11. Mortelmans K, Zeiger E. The Ames Salmonella/microsome mutagenicity assay. Mutat Res. 2000;455(1-2): 29-60. doi: 10.1016/S0027-5107(00)00064-6.

12.Ong T, Whong WZ, Stewart JD, Brockman HE. Chlorophyllin: a potent antimutagen against environmental and dietary complex mixtures. Mutat Res. 1986;173(2):111-115. doi: 10.1016/01657992(86)90086-2.

13. Negi PS, Jayaprakasha GK, Jena BS. Antioxidant and antimutagenic activities of promegranate peel extracts. Food Chem. 2003;80(3):393-397. doi: 10.1016/ S0308-8146(02)00279-0.

14. Ikken Y, Morales P, Martínez A, et al. Antimutagenic effect of fruit and vegetable ethanolic extracts against $\mathrm{N}$-nitrosamines evaluated by the Ames test. J Agric Food Chem. 1999;47(8):3257-3264. doi: 10.1021/ jf990166n.

15. Eldeen IMS, van Staden J. In vitro pharmacological investigation of extracts from some trees used in Sudanese traditional medicine. S. Afr. J. Bot. 2007;73(3):435-440. doi: 10.1016/j.sajb.2007.03.009.
16. Pandey S, Agrawal RC. Clastogenic analysis of Bauhinia variegata bark extract using micronucleus assay in mouse bone marrow cells. American-Eurasian Journal of Toxicological Sciences. 2010;2(2):112-114.

17. Yim M, Sarma BP, Sinha S, et al. Exploring the possible mechanism of Albizia lebbeck components binding with drug targets of bronchial asthma an in silico and clinical analysis. Int $J$ Pharm Sci Res. 2014;5(11):5040-5049. doi: 10.13040/IJPSR.0975-8232.5(11).5040-49.

18. Kada T, Inoue T, Namiko N. Enviromental desmutagens and antimutagens. In: Enviromental mutagenesis and plant biology. Ed by E.J. Klekowski. New York: Praiger; 1982. P. 137-151.

19. De Flora S. Mechanisms of inhibitors of mutagenesis and carcinogenesis. Mutat Res. 1998;402(1-2):151-8. doi: 10.1016/S0027-5107(97)00292-3.

20. Watanabe $M$, Ishidate $M J r$, Nohmi T. Sensitive method for detection of mutagenic nitroarenes and aromatic amines: new derivatives of Salmonella typhimurium tester strains possessing elevated O-acetyltransferase levels. Mutat Res. 1990;234(5):374-348.

21. Hagiwara Y, Watanabe M, Oda Y, et al. Specificity and sensitivity of Salmonella typhimurium YG1041 and YG1042 strains possessing elevated levels of both nitroreductase and acetyltransferase activity. Mutat Res. 1993;291(3):171-180. doi: 10.1016/01651161(93)90157-U.

22. Paul TJ, Scheepers M, Straetemans ME, Koopman JP, Bos RP. Nitroreduction and formation of hemoglobin adducts in rats with a human intestinal microflora. Environ Health Perspect.1994;102(6):39-41. doi: 10.1289/ehp.94102s639.

23. Suzuki M, Matsui K, Yamada M, et al. Construction of mutants of Salmonella typhimurium deficient in 8-hydroxyguanine DNA glycosylase and their sensitivities to oxidative mutagens and nitro compounds. $\mathrm{Mu}$ tat Res. 1997;393(3):233-246. doi: 10.1016/S13835718(97)00108-3.

24. Purohit V, Basu A. Mutagenicity of nitroaromatic compounds. Chem Res Toxicol. 2000;13(8):673-692. doi: $0.1021 /$ tx000002x.

25. Kleinhofs A, Smith JA. Effect of excision repair on azideinduced mutagenesis. Mutat Res. 1976;41(2-3): 233-240. doi: 10.1016/0027-5107(76)90096-8.

26. Veleminsky J, Angelis KJ. Effect of sodium azide on replicative and repair DNA synthesis in barley embryos. Mutat Res. 1987;190(2):15-129.

27. Owais WM, Kleinhots A. Metabolic activation of the mutagen azide in biological systems. Mutat Res. 1988;197(2):313-323. doi: 10.1016/01657992(87)90043-1.

28.Al-Qurainy F, Khan S. Mutagenic effect of sodium azide and its application in ctrop improvement. World Applied Sciences Journal. 2009;6(12):1589-1601. 
29. LaVelle JM, Mangold JB. St.ructure-activity relationships of the azide metabolite, azidoalanine, in S. typhimurium. Mutat Res. 1987;177(1):27-33. doi: 10.1016/0027-5107(87)90018-2.

30. de Mejia EG, Castano-Tostado E, Loarca-Pina G. Antimutagenic effects of natural phenolic compounds in beans. Mutat Res. 1999;441(1):1-9. doi: 10.1016/ S1383-5718(99)00040-6.

31. Martinez CJ, Loarca-Pina G, Ortiz GD. Antimutagenic activity of phenolic compounds, oligosaccharides and quinolizidinic alkaloids from Lupinus campestris seeds. Food Addit Contam. 2003;20(10):940-948. doi: 10.1080/02652030310001605998.

32.Pedreschi R, Cisneros-Zevallos L. Antimutagenic and antioxidant properties of phenolic fraction from Andean purple corn (Zea mays L.). J Agric Food Chem. 2006;54(13):4557-4567. doi: 10.1021/ jf0531050.

33. Geetha T, Saini A, Kaur IP. Ginseng extract exhibits antimutagenic activity against induced mutagenesis various strains of Salmonella typhimurium. Indian J Exp Biol. 2006;44(10):838-841.

34. Geetha T, Garg A, Chopra K, Kaur IP. Delineation of antimutagenic activity of catechin, apecatechin and green tea extract. Mutat Res. 2004;556(1-2):65-74. doi: 10.1016/j.mrfmmm.2004.07.003.

35. Santos-Cervantos ME, Ibarra-Zazueta ME, LoarcaPina G, et al. Antioxidant and antimutagenic actvivies of Randia echinocarpa fruit. Plant Foods Hum Nutr. 2007;62(2):71-77. doi: 10.1007/s1 1130-007-0044-X.

36. Kumar VC, Nagarathna PKM, Kulakarni SC, Sainadh NS. Evaluation of antimutagenic effect of flavonoid of Kigelia africana on Swiss-Albino Mice. Int J Pharm Sci Rev Res. 2013;21(1):105-108.

37. Sharma N, Bhardwaj R, Kumar S, Kaur S. Evaluation of Bauhinia variegata L. bark fractions for in vitro antioxidant potential and protective effect against $\mathrm{H}_{2} \mathrm{O}_{2}$-induced oxidative damage to pBR322 DNA. Afr J Pharm Pharmacol. 2011;5(12):1494-1500. doi: $10.5897 /$ AJPP1 1.457 . 